\title{
Alternative budburst inducers for kiwifruit vines grown in an organic system
}

\author{
Léo Omar Duarte Marques ${ }^{1}$, Paulo Mello-Farias², Rodrigo Fernandes dos Santos ${ }^{3}$, \\ Carlos Roberto Martins ${ }^{4}$, Luis Henrique Konzen ${ }^{5}$, Marcelo Barbosa Malgarim ${ }^{6}$
}

\begin{abstract}
Lack of budburst inducers is a major problem in organic production of temperate fruits. This study aimed at evaluating the effect of alternative budburst inducers on kiwifruit vines of cultivar Bruno grown in an orchard in Pelotas, Rio Grande do Sul (RS), Brazil. Inducers efficiency was investigated in both 2016-2017 and 2017-2018 seasons. The first season comprised of ten treatments, which used garlic extract at different concentrations, both, associated with and without mineral oil; Welsh onion extract at different concentrations, both associated with and without mineral oil; just mineral oil; and control (no application). In the second season, evaluation was carried out with treatments that performed well in the first season, garlic extract at different concentrations associated with mineral oil, just mineral oil and control. The following variables were evaluated: budburst percentage, phenology (budburst and flowering), fruit set, number of fruit/plant, fruit mass/ plant, estimate production, mean mass, fruit length and diameter. Results showed that $10 \%$ garlic extract $+2 \%$ mineral oil induced the highest budburst percentages in both seasons; the position of buds on branches influences budburst; apical buds exhibit the highest budburst percentage; $15 \%$ garlic extract causes phytotoxicity to buds; and Welsh onion extract is inefficient to induce budburst. Index terms: Actinidia deliciosa, dormancy, sustainability, phenology, fruit growing.
\end{abstract}

\section{Indutores de brotação alternativos para o quivizeiro cultivado em sistema orgânico}

Corresponding author: leodmq@hotmail.com

Received: October 12, 2020 Accepted: May 17, 2021

Copyright: All the contents of this journal, except where otherwise noted, is licensed under a Creative Commons Attribution License.

\section{(cc) $\mathrm{EY}$}

Resumo - A falta de indutores de brotação é um grande problema na produção orgânica de frutos de clima temperado. No presente trabalho, foi avaliado o efeito de compostos alternativos na indução de brotação em quivizeiros da cultivar Bruno implantados em um pomar, no município de Pelotas, Estado do Rio Grande do Sul, Brasil. A eficiência dos compostos foi testada nos ciclos produtivos de 2016-2017 e 2017-2018. No primeiro ciclo, aplicaram-se dez tratamentos, consistindo em extrato de alho em diferentes concentrações, associado ou não ao óleo mineral, extrato de cebolinha em diferentes concentrações, associado ou não ao óleo mineral, somente óleo mineral e controle (sem aplicação). No segundo ciclo, foram aplicados os tratamentos que se destacaram no primeiro ciclo: extrato de alho em diferentes concentrações, associado ao óleo mineral, somente óleo mineral e controle (sem aplicação). Avaliaram-se o porcentual de brotação, a fenologia (brotação e floração), a frutificação efetiva, o número de frutos/planta, a massa dos frutos/planta, a produção estimada, a massa média, o comprimento e o diâmetro dos frutos. Concluiu-se que o extrato de alho a $10 \%+$ óleo mineral a $2 \%$ induziu maiores percentuais de brotação nos dois anos de estudo; a posição da gema no ramo influencia diretamente na brotação; gemas apicais apresentam maior percentual de brotação; concentrações de $15 \%$ de extrato de alho causam fitotoxidade às gemas; e o extrato de cebolinha é ineficiente na indução da brotação.

Termos para indexação: Actinidia deliciosa, dormência, sustentabilidade, fenologia, fruticultura.

\footnotetext{
${ }^{1}$ M.Sc. in Agronomy, Agronomist, Universidade Federal de Pelotas, Capão do Leão, Rio Grande do Sul State, Brazil. E-mail: leodmq@hotmail. com $^{\text {(ORCID } 0000-0002-2232-5418) ~}$

${ }^{2} \mathrm{Ph} . \mathrm{D}$. in Sciences, Agronomist, Professor at the Horticulture and Crop Science Department. Graduate Program in Agronomy, Universidade Federal de Pelotas, Capão do Leão, Rio Grande do Sul State, Brazil. E-mail: mellofarias@yahoo.com.br ${ }^{\text {(ORCID 0000-0002-6519-4972) }}$

${ }^{3}$ M.Sc. in Agronomy, Agronomist, Universidade Federal de Pelotas, Capão do Leão, Rio Grande do Sul State, Brazil. E-mail: rodrigof. agronomia@gmail.com ${ }^{\text {(ORCID 0000-0002-7875-3868) }}$

${ }^{4} \mathrm{Ph} . D$. in Agronomy, Agronomist, Researcher at Embrapa Temperate Climate, Pelotas, Rio Grande do Sul State, Brazil. E-mail: carlos.r.martins@ embrapa.br (ORCID 0000-0001-8833-1629)

${ }_{5}^{5}$ M.Sc. in Sciences, Agronomist, Universidade Federal de Pelotas, Capão do Leão, Rio Grande do Sul State, Brazil. E-mail: luis_hkonzen@ hotmail.com (ORCID 0000-0001-7166-1373)

${ }^{6} \mathrm{Ph} . \mathrm{D}$. in Agronomy, Agronomist, Professor at the Horticulture and Crop Science Department. Graduate Program in Agronomy, Universidade Federal de Pelotas, Capão do Leão, Rio Grande do Sul State, Brazil. E-mail: malgarim@ufpel.edu.br (ORCID 0000-0002-3584-5228)
} 


\section{Introduction}

Kiwifruit (Actinidia deliciosa), which is called 'the king of fruit' in some countries due to its high content of vitamin $C$, is native to the Yangtze River region in China, even though its improvement and commercial planting began in New Zealand (ZHANG et al., 2015). Kiwifruit has great social and economic importance in several countries, such as New Zealand, Italy and Chile, because they export part of their production, which employs much workforce (HUANG et al., 2013; ZHANG et al., 2015). The world's main kiwifruit producers are China $(2,024,603 \mathrm{t}$ /year), Italy $(541,150 \mathrm{t} /$ year $)$ and New Zealand (411,783 t/year) (FAO, 2017).

Brazil imports most consumed kiwifruit from Chile and Italy, a fact that shows that the crop has potential to expand as the result of market shortage (SILVEIRA et al., 2012; MARODIN et al., 2018). As one of Brazil's main suppliers, Ihas drastically decreased kiwifruit offer due to bacterial canker, caused by Pseudomonas syringae. pv. actinidiae (PSA), that has harmed the vines. Piemonte, a region in Italy, has recently had 1,000 ha of kiwifruit vines devastated by the disease (BAUDINO et al., 2017). The fact that one of Brazil's main suppliers has had problems in its production worries the agricultural sector because kiwifruit offer may keep decreasing and prices may increase. Thus, further studies are fundamental to broaden kiwifruit production areas in Brazil.

Hydrogen cyanamide is an effective product used for overcoming bud dormancy, mainly in temperate fruit crops, such as kiwifruit and grape (Vitis vinifera) vines, and others grown in subtropical climate, such as apple trees (Malus domestica) (SUDAWAN et al., 2016). However, since this compound is very reactive and highly toxic to humans and to the environment, it cannot be applied to organic production systems. As a result, it is fundamental to carry out studies of budburst inducers that pose low or no toxicity to humans and to the environment (AMBERGER, 2013; BUENO et al., 2017).

Even though garlic extract (GE) has been investigated for about ten years as a product that induces budburst in temperate fruit trees, studies have shown different results, depending on the crop and the region. Bueno et al. (2017) used GE as a commercial product called Natualho (dosage is not mentioned) to break dormancy of fine grape vines in the west of Parana state, Brazil. The authors concluded that the amount of product used had not been enough, while Carvalho et al. (2016) obtained excellent budburst results in treatments that used GE (doses of $10 \%, 15 \%$ and $15 \%+$ mineral oil) as a budburst inducer in fine grape vines in Lavras, Minas Gerais state, Brazil. These results show the need for in-depth studies on the effects of these compounds on dormancy breaking in other regions and crops, such as kiwifruit vines grown in regions with mild winters.
Fenili et al. (2017) reported low productivity of temperate plants when they were grown in regions with subtropical climate, since they exhibited deficient budburst and flowering because of low chilling accumulation. It took place almost every year when temperate fruit trees, such as kiwifruit vines, were grown in regions with mild winters, which is a condition found in Rio Grande do Sul (RS) state, Brazil. This requires the use of budburst inducers to decrease effects of lack of chilling hours on dormancy breaking (FENILI et al., 2017).

This study aimed at evaluating the effect of alternative compounds to kiwifruit vines break dormancy of cultivar Bruno in an organic production system in Pelotas, RS, Brazil.

\section{Material and Methods}

Trials were carried out in a commercial orchard located in Cascata, Pelotas, RS (31 $58^{\prime} 30^{\prime} \mathrm{S}$ and $52^{\circ} 51^{\prime} 50^{\prime}$ 'W, altitude of $181 \mathrm{~m}$ ). The orchard of cultivar Bruno was established in 2007 in the horizontal trellis system, with $4 \times 3 \mathrm{~m}$ spacing, and the management followed the organic production principles. A plant of cultivar Matua was grown as a pollinator for every eight mother plants. In Köppen classification, climate in the region is humid subtropical (Cfa) and, in the soil taxonomy, it was classified as Argissolo. Climate data were provided by the meteorological station located at the Embrapa Clima Temperado, in Cascata, Pelotas, RS. It recorded 348 and 198 chilling hours in both 2016-2017 and 2017-2018 seasons, respectively, in agreement with the model of chilling hours proposed by Weinberger (1950) that calculated chilling hours below $7.2^{\circ} \mathrm{C}$.

Two trials were conducted. The first one was carried out in the 2016-2017 season to investigate the influence of alternative compounds that aimed at overcoming dormancy of kiwifruit vines. In the second, which occurred in the 2017-2018 season, treatments at different concentrations of GE were chosen, as the result of the fact that, in the previous year, it was superior to Welsh onion extract (WOE) associated with $2 \%$ mineral oil (MO), to $2 \% \mathrm{MO}$ alone and to the control (with no application of budburst inducers).

In the 2016-2017 season, ten treatments, with four replicates each, were applied: $5 \%$ garlic extract (5\% GE); $10 \%$ garlic extract $(10 \% \mathrm{GE}) ; 15 \%$ garlic extract $(15 \%$ GE); $2 \%$ mineral oil ( $2 \% \mathrm{MO}) ; 5 \%$ garlic extract $+2 \%$ mineral oil ( $5 \% \mathrm{GE}+2 \% \mathrm{MO}) ; 10 \%$ garlic extract $+2 \%$ mineral oil $(10 \% \mathrm{GE}+2 \% \mathrm{MO}) ; 15 \%$ garlic extract + $2 \%$ mineral oil (15\% GE $+2 \% \mathrm{MO}) ; 10 \%$ Welsh onion extract (10\% WOE); $10 \%$ Welsh onion extract $+2 \%$ mineral oil ( $10 \% \mathrm{WOE}+2 \% \mathrm{MO})$; and control, with no application (NA). 
Since some plants were found to exhibit symptoms of fungal diseases at the end of the first season, samples of soil and plant material were collected and taken to a Phytopathology laboratory to be analyzed. The soilborne fungus Ceratocystis fimbriata, which causes Ceratocystis wilt on kiwifruit, was identified. In order not to affect this study results, plants that had symptoms and the ones in the surrounding area were not used in the second season, a fact that decreased the number of plants in the trial. As a result, fewer treatments were applied in the second season, and emphasis was given to the ones that had been more promising in the first season.

In the 2017-2018 season, five treatments, with four replicates each, were applied: $2 \%$ mineral oil ( $2 \% \mathrm{MO})$; $5 \%$ garlic extract $+2 \%$ mineral oil $(5 \% \mathrm{GE}+2 \% \mathrm{MO})$; $10 \%$ garlic extract $+2 \%$ mineral oil $(10 \% \mathrm{GE}+2 \% \mathrm{MO})$; $15 \%$ garlic extract $+2 \%$ mineral oil $(15 \% \mathrm{GE}+2 \% \mathrm{MO})$; and control, with no application (NA).

The mineral oil used was Assist ${ }^{\circledR}(750 \mathrm{~mL}$ L-1 mineral oil, Basf S.A.). To prepare extracts, plants of common white garlic (Allium sativum L.) and Welsh onion (Allium fistolusum L.) were provided by an organic farmer from the countryside of Pelotas, RS. There, no chemical treatment had been used in their production management. They were harvested three days before the trial and kept in a dry, airy and shady place at room temperature.

GE was obtained from cold extraction of peeled common white garlic cloves through a juice extractor (similar to a domestic centrifugal juicer). Then, it was filtered with a cloth strainer and stored in containers wrapped in aluminum foil up to application, which was carried out right after its preparation. Yield was found in the ratio of $3: 1$ (weight/volume). The same methodology was used for extracting WOE from macerated Welsh onion leaves.

Four liters of solution were prepared for every treatment, which resulted in the application of $1 \mathrm{~L}$ per plant. An $8 \mathrm{~L}$ backpack sprayer with a fan-shaped nozzle was used for spraying all treatments on aerial parts of plants until dripping point. Application was carried out at mild temperature $\left(18^{\circ} \mathrm{C}\right.$ or below) after $5 \mathrm{pm}$.

Inducers were applied at the end of winter in both seasons. In the 2016/2017 season, inducers were applied on August 30th in phenological stage 01 (beginning of bud swelling), according to the system proposed by Salinero et al. (2009). In the 2017/2018 season, inducers were applied on September 4th with the same criteria.

Right after application, four vigorous branches per plant were selected to conduct the analysis of budding and flowering percentages. They were marked and the total number of buds was counted. Considering positions on branches, bud 1 was the apical one (AB), bud 2 was the second, and so on.
In order to calculate budburst percentages of apical and lateral buds, four evaluations were carried out. The first one was conducted 14 days after application (DAA) while the others were made at intervals of 14 days, in both trials. Evaluations consisted in counting the number of budbursts per branch and in identifying their positions on branches. Buds that were in phenological stage 10 (open bud with few visible leaves), or in more advanced ones, were considered budburst, according to the $\mathrm{BBCH}$ system for kiwifruit vines (SALINERO et al., 2009).

Numbers of budbursts per branch were compared with total numbers of buds per branch counted right after the application of inducers. It led to the budding percentage, which was obtained by the following equation: [(total number of budbursts per branch/total number of buds per branch)x100].

Regarding the phenological behavior of budburst and blooming, a branch was marked on every plant so that the following phases could be visually observed in every treatment: beginning of budburst; beginning of blooming; full blooming; and end of blooming. The beginning of budburst meant that at least $50 \%$ of buds were in phenological stage 10 , in according to the $\mathrm{BBCH}$ system (SALINERO et al. 2009). The beginning of blooming took place when plants had $5 \%$ of open flowers, while full bloom meant that more than $70 \%$ of flowers were open. The end of blooming happened when the last flowers opened.

In full blooming, the number of flower clusters per plant was counted. After natural fruit drop, 30 days after full blooming, remaining fruits were counted in every plot, and fruit set (\%) was calculated by the relation between numbers of fruit and flowers ([number of fruit/flower clusters] $\times 100$ ).

Kiwifruits were harvested when their soluble solids reached at least $6.2^{\circ} \mathrm{Brix}$, measured with a pocket refractometer, as recommended by Silveira et al. (2012), to avoid pulp vitrescence and to prevent pericarp from getting rubbery throughout preservation.

The total number of fruit per plant was verified, and, then, homogeneous samples of at least 40 fruit per plant were harvested, registered and weighed. Calculation of production per plant $(\mathrm{kg})$, estimated production $\left(\mathrm{kg} \mathrm{ha}^{-1}\right)$ and mean fruit mass $(\mathrm{g})$ were based on the harvested fruits.

Mean fruit diameter was measured by a millimeter wooden ruler. Diameters of ten fruits placed vertically side by side were analyzed, and means of fruits diameters of every plot were calculated. Mean fruit length was also measured by a millimeter wooden ruler. Length of ten fruits placed horizontally side by side (insertion point with stalk in the horizontal position) were evaluated, and means of fruit lengths of every plot were found. 
A randomized block was used as the statistical design, with four replicates. Both seasons were analyzed separately. Means were subjected to the analysis of variance. Effects of treatments were evaluated by the F-test and, when results were significant, means were compared by the Tukey's test at 5\% significance level. When necessary, quantitative factors were subjected to polynomial regression. Statistical analyses were carried out by the RStudio software program.

\section{Results and Discussion}

In the 2016-2017 season, treatments that had the highest percentage of budburst were 10\% GE $+2 \% \mathrm{MO}$ and $10 \%$ GE, which led to $77.08 \%$ and $73.96 \%$ of final budburst, respectively (Table 1). Concentrations of $10 \%$ GE were found to be the ones that exhibited the highest values in the first season, even though they differed statistically from $5 \% \mathrm{GE}$, associated with or without $\mathrm{MO}$, or from MO alone. Treatments that comprised $10 \% \mathrm{GE}$ induced high budburst percentages 28 and 42 days after application. It shows that this GE concentration made buds break faster.

Table 1. Budburst percentages of kiwifruit vines of the cultivar Bruno subjected to different budburst inducers in the 2016-2017 season, on four dates, in Pelotas-RS, Brazil.

\begin{tabular}{ccccc}
\hline \multirow{2}{*}{ Treatments } & \multicolumn{4}{c}{ DAA (days after application) } \\
\cline { 2 - 5 } & 14 & 28 & 42 & 56 \\
\hline $10 \% \mathrm{GE}+2 \% \mathrm{MO}$ & $9.37^{\text {ns }}$ & $54.16 \mathrm{a}$ & $76.04 \mathrm{a}$ & $77.08 \mathrm{a}$ \\
$10 \% \mathrm{GE}$ & 7.29 & $41.66 \mathrm{ab}$ & $72.91 \mathrm{ab}$ & $73.95 \mathrm{ab}$ \\
$5 \% \mathrm{GE}$ & 7.29 & $36.45 \mathrm{bc}$ & $69.79 \mathrm{abc}$ & $69.79 \mathrm{abc}$ \\
$2 \% \mathrm{MO}$ & 5.20 & $31.25 \mathrm{bc}$ & $61.45 \mathrm{abcd}$ & $68.75 \mathrm{abc}$ \\
$5 \% \mathrm{GE}+2 \% \mathrm{MO}$ & 6.25 & $30.20 \mathrm{bc}$ & $65.62 \mathrm{abcd}$ & $66.66 \mathrm{abcd}$ \\
$10 \% \mathrm{WOE}+2 \% \mathrm{MO}$ & 6.25 & $28.12 \mathrm{bc}$ & $58.33 \mathrm{bcde}$ & $60.41 \mathrm{bcd}$ \\
$10 \% \mathrm{WOE}$ & 6.25 & $30.20 \mathrm{bc}$ & $55.20 \mathrm{cde}$ & $55.20 \mathrm{~cd}$ \\
No application & 1.04 & $09.37 \mathrm{~d}$ & $48.95 \mathrm{e}$ & $52.08 \mathrm{~d}$ \\
$15 \% \mathrm{GE}+2 \% \mathrm{MO}$ & 3.12 & $28.12 \mathrm{bc}$ & $50.00 \mathrm{de}$ & $52.08 \mathrm{~d}$ \\
$15 \% \mathrm{GE}$ & 3.12 & $20.83 \mathrm{~cd}$ & $45.83 \mathrm{e}$ & $51.04 \mathrm{~d}$ \\
\hline
\end{tabular}

${ }^{1}$ Means followed by different small letters in columns differ by the Tukey's test ( $\left.\mathrm{p} \leq 0.05\right)$ significance level; ${ }^{2} \mathrm{~ns}$ - not significant. GE - garlic extract; MO - mineral oil; WOE - Welsh onion extract

Biasi et al. (2010) applied GE to kiwifruit vines of the cultivar Bruno in Pinhais, Paraná (PR) state. The authors found that the best treatment for the variable budburst was also the concentration at $10 \%$. It corroborates with the results of the study described by this paper, and it shows that this concentration is the ideal one to enable the best budburst.

Results found by Biasi et al. (2010) exhibited lower values of budburst than the ones from this study in the first season, since they reported mean budburst of $52.50 \%$ in the treatment with $10 \% \mathrm{GE}+4 \% \mathrm{MO}$. The fact that results of budburst found by this study in the 2016-2017 season were better than the ones reported by Biasi et al. (2010) is due to the number of chilling hours. In Pinhais, PR, in the period under study, there were 209 hours below $7.2^{\circ} \mathrm{C}$, calculated by the model proposed by Weinberger (1950), while, in Pelotas, RS, there were 348 hours below $7.2{ }^{\circ} \mathrm{C}$ (same model) in the period investigated by this study. Thus, the last one showed better conditions for plants to rest and better budburst when their dormancy stage finished.
Even though Welsh onion and garlic belong to the same family (Amaryllidaceae) and genus (Allium spp.), the first one did not exhibit the efficiency of the last one in treatments carried out in the first season, since its maximum percentage of budburst was $60.4 \%$ (Table 1). Garlic is efficient to break dormancy, since its extract is rich in diallyl disulfide, a compound that destroys glutathione and increases $\mathrm{H}_{2} \mathrm{O}_{2}$ levels when in contact with buds. As a result, it leads to respiratory alteration, inhibits glucose enzymes, changes carbon flow, triggers metabolic modifications and favors the expression of SNF-like protein-kinases, which transfer the signal that ends bud dormancy (PERUSSI, 2010; El-AMARY and EL-HAMIED, 2018). Low efficiency of Welsh onion as a budburst inducer may be a result from the fact that it does not have high concentrations of diallyl disulfide. 
There were interactions between treatments and buds on branches (Table 2), since, when apical buds were evaluated, all treatments were more efficient than the one with no application, which exhibited $50 \%$ of budburst. Treatments of $5 \% \mathrm{GE}+2 \% \mathrm{MO}, 10 \% \mathrm{GE}$ and $5 \% \mathrm{GE}$ reached about $80 \%$ of apical budburst. Results were similar to the ones of hydrogen cyanamide application to kiwifruit vines reported by Pichakum et al. (2018), who observed that this compound led to significant increase in their budburst rate and differences in results, depending on the position of buds on branches.

Table 2. Budburst percentages of apical buds (AB), bud 1 (B1), bud 2 (B2), bud 3 (B3), bud 4 (B4) and bud 5 (B5) of kiwifruit vines of the cultivar Bruno subjected to different budburst inducers in the 2016-2017 season in PelotasRS, Brazil.

\begin{tabular}{ccccccc}
\hline \multirow{2}{*}{ Treatment } & \multicolumn{7}{c}{ Bud position } \\
\cline { 2 - 7 } & $\mathrm{AB}$ & $\mathrm{B} 1$ & $\mathrm{~B} 2$ & $\mathrm{~B} 3$ & $\mathrm{~B} 4$ & $\mathrm{~B} 5$ \\
\hline $10 \% \mathrm{GE}$ & $84.37 \mathrm{a} \mathrm{A}$ & $65.62 \mathrm{a} \mathrm{B}$ & $54.68 \mathrm{a} \mathrm{BC}$ & $32.81 \mathrm{ab} \mathrm{DE}$ & $39.06 \mathrm{ab} \mathrm{CD}$ & $17.18 \mathrm{ab} \mathrm{E}$ \\
$5 \% \mathrm{GE}$ & $81.25 \mathrm{a} \mathrm{A}$ & $48.43 \mathrm{abc} \mathrm{B}$ & $48.43 \mathrm{a} \mathrm{bB}$ & $42.18 \mathrm{ab} \mathrm{BC}$ & $25.00 \mathrm{bc} \mathrm{C}$ & $29.68 \mathrm{ab} \mathrm{C}$ \\
$5 \% \mathrm{GE}+2 \% \mathrm{MO}$ & $81.25 \mathrm{aA}$ & $54.68 \mathrm{ab} \mathrm{B}$ & $40.62 \mathrm{ab} \mathrm{BC}$ & $18.7 \mathrm{c} \mathrm{D}$ & $28.12 \mathrm{bc} \mathrm{CD}$ & $29.68 \mathrm{ab} \mathrm{CD}$ \\
$10 \% \mathrm{GE}+2 \% \mathrm{MO}$ & $79.68 \mathrm{ab} \mathrm{A}$ & $67.18 \mathrm{a} \mathrm{AB}$ & $45.31 \mathrm{ab} \mathrm{CD}$ & $46.87 \mathrm{a} \mathrm{CD}$ & $53.12 \mathrm{aB} \mathrm{C}$ & $32.81 \mathrm{a} \mathrm{D}$ \\
$10 \% \mathrm{WOE}+2 \% \mathrm{MO}$ & $75.00 \mathrm{ab} \mathrm{A}$ & $53.12 \mathrm{abc} \mathrm{B}$ & $32.81 \mathrm{bc} \mathrm{C}$ & $18.75 \mathrm{c} \mathrm{C}$ & $26.56 \mathrm{bc} \mathrm{C}$ & $23.43 \mathrm{ab} \mathrm{C}$ \\
$2 \% \mathrm{MO}$ & $73.43 \mathrm{ab} \mathrm{A}$ & $54.68 \mathrm{ab} \mathrm{B}$ & $32.81 \mathrm{bc} \mathrm{C}$ & $35.93 \mathrm{abC}$ & $21.87 \mathrm{bc} \mathrm{C}$ & $31.25 \mathrm{a} \mathrm{C}$ \\
$10 \% \mathrm{WOE}$ & $71.87 \mathrm{ab} \mathrm{A}$ & $54.68 \mathrm{ab} \mathrm{A}$ & $28.12 \mathrm{c} \mathrm{B}$ & $25.00 \mathrm{bc} \mathrm{B}$ & $14.06 \mathrm{c} \mathrm{B}$ & $26.56 \mathrm{ab} \mathrm{B}$ \\
$15 \% \mathrm{GE}$ & $65.62 \mathrm{abc} \mathrm{A}$ & $34.37 \mathrm{c} \mathrm{B}$ & $26.56 \mathrm{c} \mathrm{BC}$ & $18.75 \mathrm{c} \mathrm{BC}$ & $20.31 \mathrm{bc} \mathrm{BC}$ & $15.62 \mathrm{ab} \mathrm{C}$ \\
$15 \% \mathrm{GE}+2 \% \mathrm{MO}$ & $60.93 \mathrm{bc} \mathrm{A}$ & $42.18 \mathrm{bc} \mathrm{B}$ & $31.25 \mathrm{bc} \mathrm{BC}$ & $34.37 \mathrm{ab} \mathrm{BC}$ & $20.31 \mathrm{bc} \mathrm{CD}$ & $10.93 \mathrm{~b} \mathrm{D}$ \\
No application & $50.00 \mathrm{c} \mathrm{A}$ & $35.93 \mathrm{bc} \mathrm{AB}$ & $26.56 \mathrm{c} \mathrm{BC}$ & $26.56 \mathrm{bc} \mathrm{BC}$ & $17.18 \mathrm{c} \mathrm{C}$ & $10.93 \mathrm{~b} \mathrm{C}$ \\
\hline
\end{tabular}

${ }^{1}$ Means followed by different small letters in columns and capital letters on lines differ by the Tukey's test $(\mathrm{p} \leq 0.05)$ significance level. GE - garlic extract; MO - mineral oil; WOE - Welsh onion extract

Regarding their positions on branches (Table 2), in general, buds were found to follow a linear budburst order. The apical bud was the first, followed by buds 1 and 2, little variation between the 3rd and the 4th buds, and then the 5 th bud. Budburst percentages decreased as buds were farther away from the branch apex, towards the base. According to Pichakum et al. (2018), apical budburst, which may often reach $100 \%$, predominates in kiwifruit vines, while buds that are farther away from the branch apex exhibit gradual decrease in budburst percentages.

Marodin et al. (2018) explained why apical buds break first. They suggest that the highest budburst on the apex is due to correlative inhibition, which basically means that basal buds on branches do not break because of the existing apical dominance. It inhibits activity of basal buds and allows only the basal bud to break after the apical one (the dominant one). The authors report that, physiologically, it takes place because the apical bud produces auxin, which leads to inhibition of basal buds on branches.
In the first two evaluations in the 2017-2018 season, 14 and 28 DAA, there were no significant differences among treatments (Table 3). At 42 DAA, the treatment with $10 \% \mathrm{GE}+2 \% \mathrm{MO}$ exhibited the highest budburst percentage, but it did not differ statistically from the treatment with $5 \% \mathrm{GE}+2 \% \mathrm{MO}$. At $56 \mathrm{DAA}$, the treatment with $10 \% \mathrm{GE}+2 \%$ MO kept exhibiting the highest budburst percentage, which was $62.5 \%$. The highest budburst percentage in this cycle was also higher than the best results found by Biasi et al. (2010), who reported $52.50 \%$ with $10 \% \mathrm{GE}+4 \% \mathrm{MO}$ in a cycle with 198 chilling hours, calculated by the model proposed by Weinberger (1950). It was similar to the number of chilling hours in Pinhais, PR (209 hours, calculated by the same model), where Biasi et al. (2010) carried out their trial. Results reinforce the good performance of certain GE concentrations - shown by the study reported on this paper - concerning budburst percentages, even in years with few chilling hours.

Figure 1 shows the effect on budburst dynamics throughout all four evaluations, polynomial equations generated by interactions between treatments and evaluation dates. The treatment with $10 \% \mathrm{GE}+2 \% \mathrm{MO}$ exhibited the best budburst percentages. The treatment with 15\% GE reached the lowest percentages of broken buds, even lower than the one of the control (with no application), a fact that implies certain phytotoxicity at this GE concentration on kiwifruit vines branches. 
Table 3. Budburst percentages of kiwifruit vines of the cultivar Bruno subjected to different budburst inducers in the 2017-2018 season, on four dates, in Pelotas-RS, Brazil.

\begin{tabular}{ccccc}
\hline \multirow{2}{*}{ Treatment } & \multicolumn{4}{c}{ DAA (days after application) } \\
\cline { 2 - 5 } & 14 & 28 & 42 & 56 \\
\hline $10 \% \mathrm{GE}+2 \% \mathrm{MO}$ & $5.20^{\mathrm{ns}}$ & $16.66^{\mathrm{ns}}$ & $44.79 \mathrm{a}$ & $62.50 \mathrm{a}$ \\
$5 \% \mathrm{GE}+2 \% \mathrm{MO}$ & 1.04 & 08.33 & $42.70 \mathrm{ab}$ & $50.00 \mathrm{~b}$ \\
$2 \% \mathrm{MO}$ & 0.00 & 07.29 & $33.33 \mathrm{bc}$ & $44.79 \mathrm{~b}$ \\
$15 \% \mathrm{GE}+2 \% \mathrm{MO}$ & 2.08 & 13.54 & $29.16 \mathrm{c}$ & $33.33 \mathrm{c}$ \\
No application & 2.08 & 10.41 & $32.29 \mathrm{c}$ & $43.75 \mathrm{~b}$ \\
\hline
\end{tabular}

${ }^{1}$ Means followed by different small letters in columns differ by the Tukey's test at ( $\left.\mathrm{p} \leq 0.05\right)$ significance level; ${ }^{2} \mathrm{~ns}$ - not significant. GE - garlic extract; MO - mineral oil

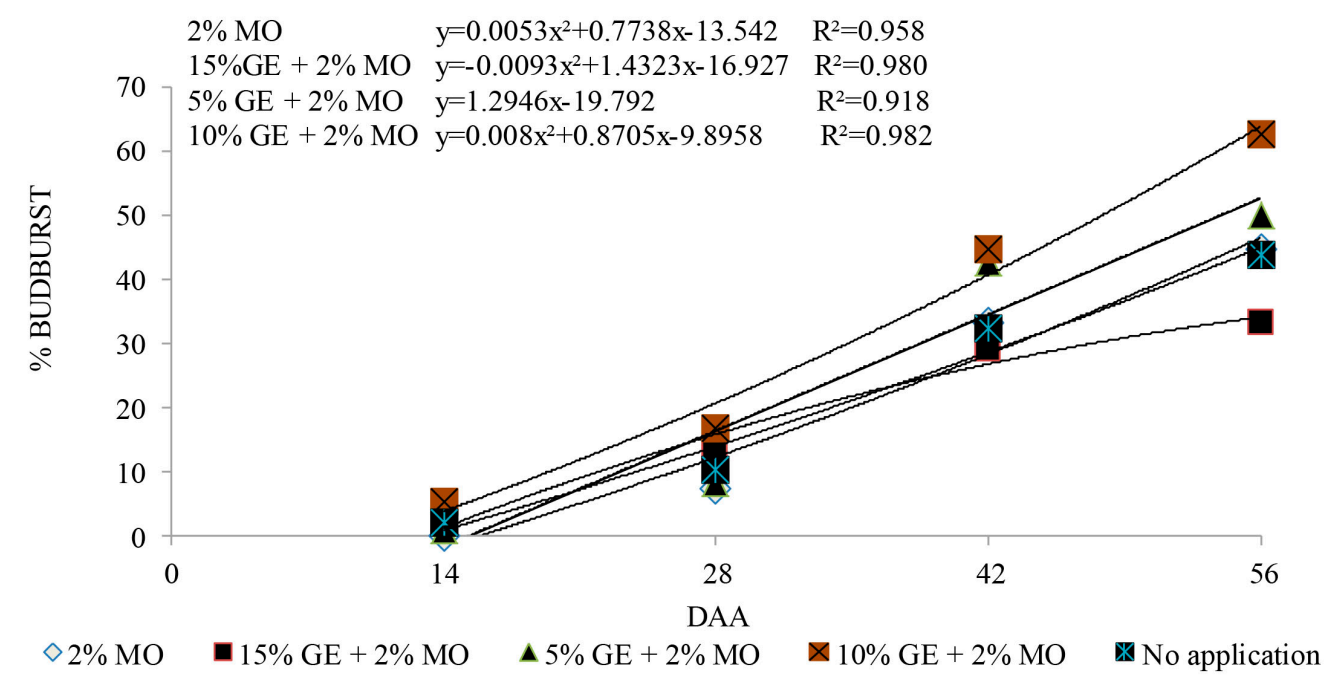

Figure 1. Budburst percentages of kiwifruit vines of the cultivar Bruno subjected to different budburst inducers in the 2017-2018 season in Pelotas-RS, Brazil.GE - garlic extract; MO - mineral oil

Even though the treatment with $10 \% \mathrm{GE}+2 \%$ MO was the best in both seasons under evaluation, the final percentage decreased about $15 \%$ in the second year. The main reason for this was the difference in chilling accumulation, since there were 348 chilling hours in the first season and 198 chilling hours below $7.2{ }^{\circ} \mathrm{C}$ in the second season, according to the model proposed by Weinberger (1950).

Table 4 shows production parameters in both 20162017 and 2017-2018 seasons. In the first one, fruit set, besides fruit mass, length and diameter were not affected by any treatment application. Number of fruits per plant was 388 , on average, when $10 \% \mathrm{GE}+2 \% \mathrm{MO}$ was applied. The lowest number of fruit per plant was found when $15 \% \mathrm{GE}+2 \% \mathrm{MO}$ was applied. It means 298.25 fruits per plant, and it was lower that the number yielded by the treatment with no application. Again, it may show that GE exhibits phytotoxicity at this concentration.
Production per plant (Table 4) was affected by the application of different treatments. The best results - about $25 \mathrm{~kg} / \mathrm{plant}^{-1}$ - were found when $5 \% \mathrm{GE}+2 \% \mathrm{MO}, 10 \%$ $\mathrm{GE}+2 \% \mathrm{MO}$ and $10 \% \mathrm{GE}$ were applied. These treatments also had the highest means of estimated production. It happened mainly in the treatment with $10 \% \mathrm{GE}+2 \% \mathrm{MO}$, whose mean was about $22 \mathrm{tha}^{-1}$, which is around $3 \mathrm{tha}^{-1}$ higher than the one of the control treatment.

Concerning phenology, treatments with GE brought budburst forward, as well as beginning and full blooming, when comparing with the control treatment, in both seasons under study, even though there was little difference among treatments (Table 5). According to Hawerroth et al. (2009), when temperate fruit trees bring blooming forward, fruit develops better due to the longer period on the plant. Thus, bringing blooming forwards with the use of budburst inducers may be more relevant to blooming synchronization between cultivars of interest and their pollinators, rather than to bring fruit ripening forward (HAWERROTH et al., 2009). 
Table 4. Production and biometric parameters of kiwifruit vines of the cultivar Bruno: fruit set (FS), number of fruit per plant (FP), total fruit mass per plant (PM), fruit mass (FM), estimated production (EP), length (L) and diameter (D) of fruit subjected to different budburst inducers in two seasons (2016-2017 and 2017-2018) in Pelotas-RS, Brazil.

\begin{tabular}{|c|c|c|c|c|c|c|c|}
\hline \multicolumn{8}{|c|}{ 2016-2017 season $* * *$} \\
\hline Treatment & FS $(\%)$ & FP (fruit/plant ${ }^{-1}$ ) & PM (kg) & $\mathrm{FM}(\mathrm{g})$ & $\operatorname{EP}\left(\mathrm{t} \cdot \mathrm{ha}^{-1}\right)$ & $\mathrm{L}(\mathrm{cm})$ & $\mathrm{D}(\mathrm{cm})$ \\
\hline $10 \% \mathrm{GE}+2 \% \mathrm{MO}$ & $71.35^{\mathrm{ns}}$ & $387.8 \mathrm{a}$ & $27.40 \mathrm{a}$ & $71.02^{\mathrm{ns}}$ & $22.83 \mathrm{a}$ & $78.10^{\mathrm{ns}}$ & $40.57^{\mathrm{ns}}$ \\
\hline $10 \% \mathrm{GE}$ & 69.20 & $356.5 \mathrm{abc}$ & $26.00 \mathrm{a}$ & 72.90 & $21.66 \mathrm{a}$ & 78.55 & 40.67 \\
\hline $2 \% \mathrm{MO}$ & 66.50 & $360.8 \mathrm{ab}$ & $25.52 \mathrm{ab}$ & 71.92 & $21.61 \mathrm{ab}$ & 77.73 & 40.32 \\
\hline $5 \% \mathrm{GE}+2 \% \mathrm{MO}$ & 73.85 & $361.0 \mathrm{ab}$ & $25.84 \mathrm{a}$ & 71.55 & $21.52 \mathrm{ab}$ & 77.50 & 40.45 \\
\hline $10 \% \mathrm{WOE}$ & 59.79 & $349.3 \mathrm{abc}$ & $25.54 \mathrm{ab}$ & 69.10 & $20.12 \mathrm{ab}$ & 77.25 & 39.75 \\
\hline $10 \% \mathrm{WOE}+2 \% \mathrm{MO}$ & 66.66 & $343.0 \mathrm{abc}$ & $24.26 \mathrm{ab}$ & 71.65 & $20.44 \mathrm{ab}$ & 78.55 & 40.40 \\
\hline $5 \% \mathrm{GE}$ & 69.80 & $358.8 \mathrm{abc}$ & $24.46 \mathrm{ab}$ & 68.40 & $20.38 \mathrm{ab}$ & 77.20 & 39.95 \\
\hline $15 \% \mathrm{GE}$ & 66.90 & $351.5 \mathrm{abc}$ & $23.68 \mathrm{ab}$ & 67.40 & $19.72 \mathrm{ab}$ & 77.37 & 40.87 \\
\hline No application & 66.88 & $324.3 \mathrm{bc}$ & $22.90 \mathrm{ab}$ & 70.70 & $19.08 \mathrm{ab}$ & 78.40 & 40.40 \\
\hline $15 \% \mathrm{GE}+2 \% \mathrm{MO}$ & 66.16 & $298.3 \mathrm{c}$ & $20.90 \mathrm{~b}$ & 70.77 & $17.58 \mathrm{~b}$ & 78.28 & 40.37 \\
\hline \multirow[t]{2}{*}{ C.V. $(\%)$} & 10.11 & 7.25 & 7.96 & 6.12 & 8.24 & 3.45 & 3.59 \\
\hline & \multicolumn{7}{|c|}{ 2017-2018 season $* * * *$} \\
\hline Treatment & FS $(\%)$ & $\begin{array}{c}\text { FP } \\
\text { (fruit.pl }^{-1} \text { ) }\end{array}$ & PM (Kg) & $\mathrm{FM}(\mathrm{g})$ & $\mathrm{EP}\left(\mathrm{t} \cdot \mathrm{ha}^{-1}\right)$ & $\mathrm{L}(\mathrm{cm})$ & $\mathrm{D}(\mathrm{cm})$ \\
\hline $2 \% \mathrm{MO}$ & $61.56^{\mathrm{ns}}$ & $242.25^{\mathrm{ns}}$ & $16.94^{\mathrm{ns}}$ & $70.00^{\text {ns }}$ & $14.11^{\mathrm{ns}}$ & $74.95^{\mathrm{ns}}$ & $37.00^{\text {ns }}$ \\
\hline $15 \% \mathrm{GE}+2 \% \mathrm{MO}$ & 61.15 & 226.25 & 15.91 & 70.22 & 13.25 & 76.06 & 36.70 \\
\hline $5 \% \mathrm{GE}+2 \% \mathrm{MO}$ & 63.80 & 258.25 & 18.05 & 70.05 & 15.04 & 75.55 & 36.30 \\
\hline $10 \% \mathrm{GE}+2 \% \mathrm{MO}$ & 61.63 & 255.50 & 17.14 & 70.10 & 14.91 & 77.65 & 36.95 \\
\hline No application & 59.86 & 238.00 & 16.62 & 70.35 & 15.04 & 76.35 & 36.65 \\
\hline C.V $(\%)$ & 11.58 & 9.45 & 10.80 & 4.20 & 9.65 & 4.06 & 5.37 \\
\hline
\end{tabular}

${ }^{1}$ Means followed by different small letters in columns differ by the Tukey's test at $(\mathrm{p} \leq 0.05)$ significance level; ${ }^{2} \mathrm{~ns}$ - not significant.GE - garlic extract; MO - mineral oil; WOE - Welsh onion extract 
Table 5. Checking dates of the following phenological stages: beginning of budburst (BB), beginning of blooming (BB1), full blooming (FB) and harvest of kiwifruit vines of the cultivar Bruno subjected to different budburst inducers in both seasons (2016-2017 and 2017-2018) in Pelotas-RS, Brazil.

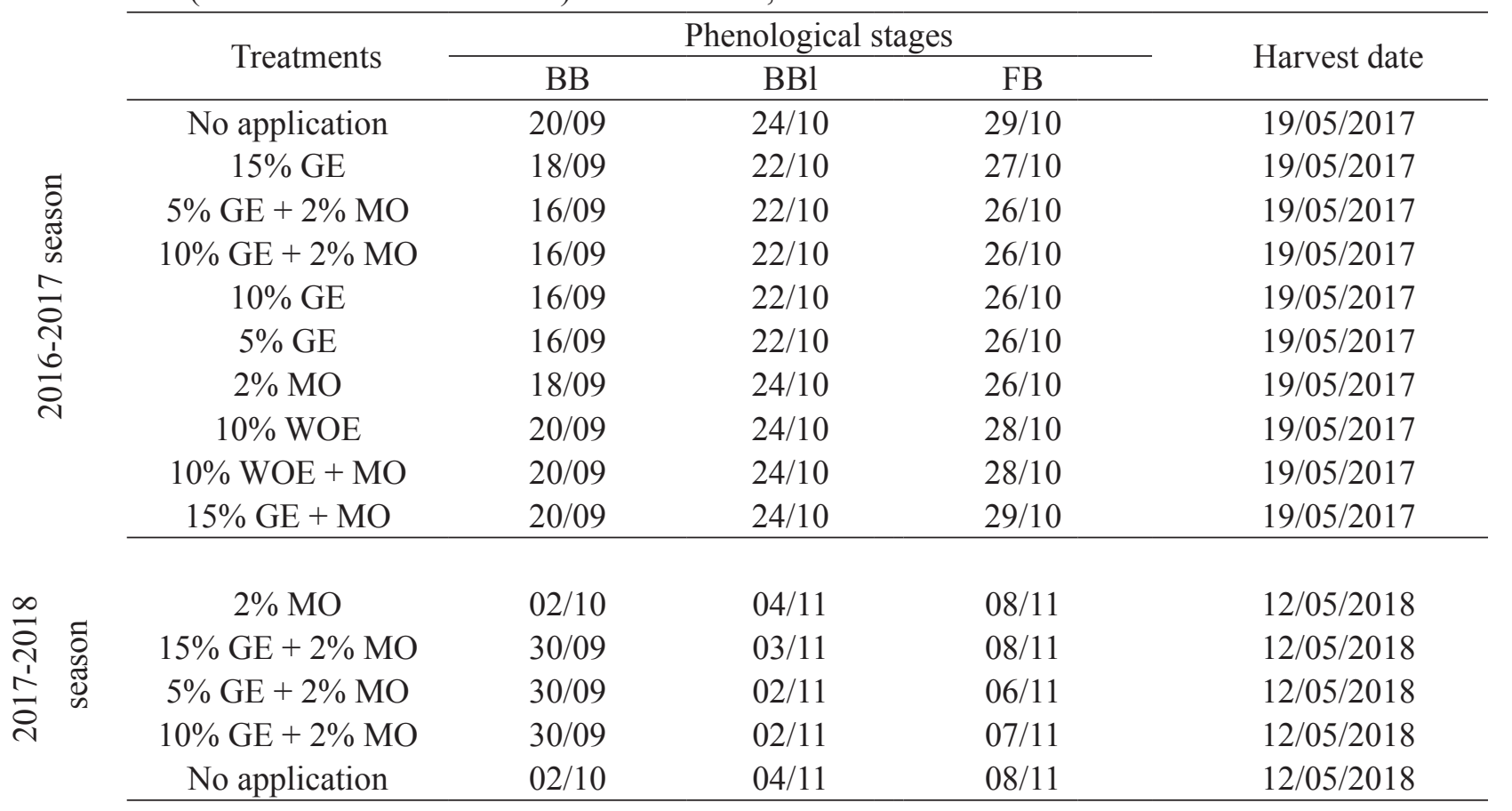

GE - garlic extract; MO - mineral oil; WOE - Welsh onion extract

According to Marchi et al. (2017), the use of artificial techniques, such as budburst inducers to break dormancy, helps to mitigate consequences of lack of cold, even though it does not solve it completely. Other factors, such as natural chilling accumulation, plant age and plant vigor, must be considered. This explains results found by the study reported by this paper, since, in the second season, when chilling accumulation was lower, budburst inducers could not repeat the results of the first one. According to Silveira et al. (2012), the cultivar Bruno requires about 300 chilling hours, which means that budburst inducers mitigated the problem of low chilling accumulation but they could not compensate for it completely. Thus, budburst percentages were lower in the second season.

Results showed that $10 \% \mathrm{GE}$, together with $2 \%$ MO, was constant in both seasons and exhibited the highest budburst percentages. Besides, some treatments, such as $15 \%$ GE, associated with and without MO, and WOE, which was inefficient in all treatments, are not recommended due to their probable phytotoxicity.

\section{Conclusions}

The treatment, which comprises $10 \%$ garlic extract $+2 \%$ mineral oil, is the most efficient one for budburst of 'Bruno' kiwifruit vines grown in an organic system.

Position of buds on branches influences budburst, so apical buds have higher budburst percentage than buds on the base of branches.

Concentrations close to $15 \%$ garlic extract $+2 \%$ mineral oil cause phytotoxicity on buds, and the use of Welsh onion extract is inefficient to induce budburst.

\section{Acknowledgements}

The authors thank the Coordenação de Aperfeiçoamento de Pessoal de Nível Superior - CAPES (Coordination for the Improvement of Higher Education Personnel) for its financial support. 


\section{References}

AMBERGER, A. Cyanamide in plant metabolism. International Journal of Plant Physiology and Biochemistry, Ismalia, v.5, n.1, p.1-10, 2013.

BAUDINO, C.; GIUGGIO, N.R.; BRIANO, R.; MASSAGLIA, S.; PEANO, C. Integrated methodologies (SWOT, TOWS, LCA) for improving production chains and environmental sustainability of Kiwifruit and Baby Kiwi in Italy. Sustainability, Basiléia, v.9, n.9, p.1621, 2017.

BUENO, T.F.; VILLA, F.; ROSA, D.D.; STUMM, D.R. Uso de produto à base de alho associado à poda no desempenho de videiras finas no oeste paranaense. Revista Ceres, Viçosa, MG, v.64, n.4, p.426-432, 2017.

BIASI, L.A.; LIPSKI, B.; SILVA, E.D.; OLIVEIRA, O.D.; SACHI, A.T.; PERESSUTI.; R.A. Calda sulfocálcica, óleo mineral e extrato de alho na superação da dormência de quivizeiro. Revista de Ciências Agroveterinárias, Lages, v.9, n.1, p.58-65, 2010.

CARVALHO, J.N.; PEREIRA, L.S.; CARVALHO, P.A; DECARLOS NETO, A. Application of natural garlic extract to overcome bud dormancy of grapevines 'BRS Rúbea' and 'BRS Cora'. Australian Journal of Crop Science, Lismore, v.10, n.2, p.216-219, 2016.

EL-AMARY, E.I.; EL-HAMIED, A.A. A comparative study between garlic extract and hydrogen cyanamide on flowering, fruit set and productivity of grapes. Egyptian Journal of Desert Research, Cairo, v.68 n.2, p.199-222, 2018.

FAO - Food and Agriculture Organization of the United Nations. Faostat. Rome, 2017. Disponível em: http:// www.fao.org/faostat/es/\#data/QC. Acesso em: 06 nov. 2019.

FENILI, C.L.; GABARDO, G.C.; PETRI, J.L.; SEZERINO, A.A.; MARTIN, M.S. Bluprins ${ }^{\circledR}$ em alternativa como indutor de brotação da macieira. Revista da Jornada de Pós-Graduação e Pesquisa-Congrega Urcamp, Bagé, v.14, n.1, p.860-868, 2017.
HAWERROTH, F.J.; PETRI, J.L., HERTER, F.G.; LEITE, G.B.; LEONETTI, J.F.; MARAFON, A.C.; SIMÕES F. Fenologia, brotação de gemas e produção de frutos de macieira em resposta à aplicação de cianamida hidrogenada e óleo mineral. Bragantia, Campinas, v.68, n.4, p.961-971, 2009.

HUANG, S.; DING, J.; SHENGXIONG, H.; JIAN, D.; DEJING, D.; WEI, T.; et al. Genome of the kiwi fruit Actinidiachinensis. Nature Communications, London, v.4, p.2640, 2013.

MARCHI, T.; OLIARI, I.C.R.; MAIA, A.J.; SATO, A.J.; BOTELHO, R.V. Indução da brotação de gemas de macieiras com aplicação de óleos vegetais e mineral. Revista Ciência Agronômica, Fortaleza, v.48, n.3, p.501512, 2017.

MARODIN, F.A.; SOUZA, P.V.D.; SILVEIRA, S.V.D.; GUASSO, L.Z.; LAZAROTTO, M.; SASSI, A. Vegetative and productive behavior of kiwifruit 'Elmwood' submitted to pruning with different bud loading levels. Revista Brasileira de Fruticultura, Jaboticabal, v.40 n.6, 2018.

PERUSSI, G.P.; G.; BOTELHO, R.V.; RICKLLI, E.; PAVANELLO, A.P. Quebra de dormência em macieiras 'Fuji Kiku' com uso de extrato de alho. Revista Semina, Londrina, v.31, n.2, p.313-320, 2010.

PICHAKUM, A.; CHAIWIMOL, W.; MEETAM, M.; SONGNUAN, W. Responses of green kiwifruit grown in low-chill area to hydrogen cyanamide application. Acta Horticulturae, Leuven, v.1206, n.14, p.97-104, 2018.

SALINERO, M.C.; VELA, P.; SAINZ, M.J. Phenological growth stages of kiwifruit (Actinidiadeliciosa'Hayward'). Scientia Horticulturae, Amsterdam, v.121, n.1, p.27-31, 2009.

SILVEIRA, S.V.; ANZANELLO, R.; SIMONETTO, P.R.; GAVA, R.; GARRIDO, L.R.; SANTOS, R.S.S.; GIRARDI, C.L. Aspectos técnicos da produção do quivi. Bento Gonçalve: EMBRAPA, 2012. (Documentos, 79) 
SUDAWAN, B.; CHANG, C.S.; CHAO, H.F.; KU, M.S.B.; YEN, Y.F. Hydrogen cyanamide breaks grapevine bud dormancy in the summer through transient activation of gene expression and accumulation of reactive oxygen and nitrogen species. BMC Plant Biology, London, v.16, n.1, p.202, 2016.
WEINBERGER, J.H. Chilling requirements of peach varieties. Proceedings of the American Society for Horticultural Science, Geneva, v.56, p.122-128, 1950.

ZHANG, H.Y.; LIU, H.M.; LIU, X.Z. Production of transgenic kiwifruit plants harboring the SbtCry1Ac gene. Genetics and Molecular Research, Ribeirão Preto, v.14, p.8483-8489, 2015. 